\title{
THE DEVELOPMENT OF LOW-COUNTRY TUSSOCK GRASSLAND
}

\author{
By G. STEVENSON, Dacre.
}

As much of the better country has been developed, it has become increasingly necessary to turn to the improvement of the poorer types.

The type under review is one of the weakly podsolised yellow-brown earths. These soils have been developed under bush and manuka on the older river terraces and on some of the loess-covered downs. The soils developed under red tussock also fall into this group. Leached and impoverished to varying degrees, these are widely represented in Southland and are capable of development to a high level of production.

The rapid increases in production of the sheep industry in Southland over the past 20 years have been accomplished largely through the development of the extensive ploughable areas of these podsolic soils.

An indication of the increasing productivity of the province is shown in the number of mature sheep and lambs killed. For the ten-year period 1923 to 1932 an average of 596,114 were killed each year. There has since been a steady and consistent rise each year until in 1949-50 when 2,309,088 were killed, an additional 300,000 or so being killed at works outside the province.

If stock-carrying capacity is expressed as units per acre of sown grassland, a comparison of the southern area with the Waikato shows that the carrying capacity is almost equal in the two regions. There is every reason to believe that the constant and steady progress being made in Southland will continue for many years to come.

In general terms it may be said that the increase in production has been brought about by more intensive drainage, heavier liming and top-dressing, the use of superior strains of pasture plants, and improved pasture management. 
In recent years the hard and arduous work previously associated with the development and breaking in of new land has been considerably lessened by the use of modern heavy machinery and equipment with which this province is fairly well equipped. In 1948 there were 43 drag-line excavators carrying out drainage and agricultural work.

Evidence of this may be seen in all parts of the province. This is being followed by mechanical ditch diggers, the limiting factor in their greater use being the supply of field tiles. The progress of tidying up swamps and drainage runners is also adding to the appearance and productivity of the province.

Generally speaking, the farmers of the province are well equipped with power and equipment. Were it possible to have a freer exchange of land there is little doubt that land development would boom. In my opinion the greatest factor in the development of land in New Zealand has been the experienced and established farmer seeking to use his equipment and resources and at the same time making provision for his family. There is no more economical way of development than where the existing power plant, stock, and labour are all utilised to their fullest extent by the experienced farmer. The development of the

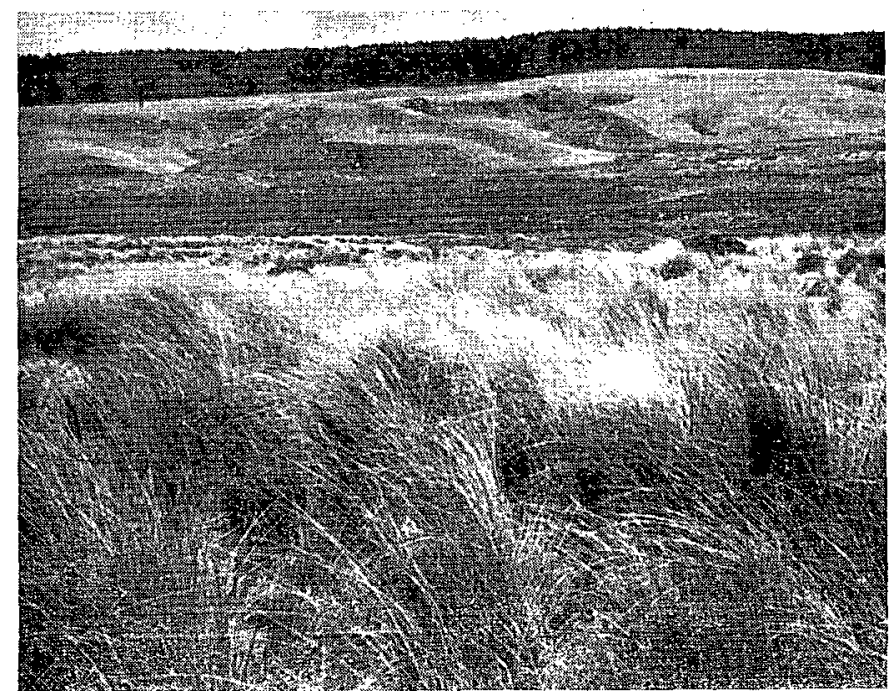

Fig I.-Unimproved red-tussock grassland in the foreground. In the distance is country being prepared for the sowing of winter feed crops. 
past has been one of progress and achievement. Much of our marginal land today could be readily developed under favourable land laws such as exist in Great Britain.

The 1,100-acre property under review was previously sold to an afforestation company because at that time the land was regarded as being more suitable for growing trees than it was for farming. The whole area was in heavy red tussock with a little manuka and odd patches of silver tussock. The property consists of low ridges which are broken in parts together with a large swamp running throughout its length.. The soil is free and light, varying from 5in. to 9in. in depth. The sub-soil is mainly a free, sandy yellow clay. On the whole the ridges are dry and do not require draining. The $\mathrm{pH}$ of the soil is 4 to 4.2 in its natural state.

The property has been under development since 1938 and has been supported by the 320-acre home farm from which labour, plant, and stock have been made available. Development has gone on in easy stages, the availability of labour, lime, fertilisers and fencing materials being the chief limiting factors. Sufficient land was brought in to grow enough winter feed for the home flock of 1,200 ewes, the home farm in the meantime being practically all sown down to pasture. The sheep were removed to swedes and other winter feed for approximately 8 weeks during the winter. The cultivation programme has been to plough and fallow the land for one year. Owing to the density and bulk of the tussock growth, this is usually burnt before ploughing. In the early stages of development, however, it was not possible to burn on account of an adjoining plantation. Ploughing is carried out with a heavy single-furrow swamp plough turning a furrow $8 \mathrm{in}$. deep and 20in. wide.

Following the application of one ton lime per acre, the area is sown in swedes and turnips during November. These are sown with the ridger at the rate of 11oz. and 8oz. per acre respectively together with 3 cwt. per acre of turnip manure or reverted super-, phosphate. The land is clean and free from weeds and no scuffling or inter-row cultivation is carried out, largely on account of the presence of tussock roots and in parts because of the steepness of the land. The turnips and swedes are fed off along with hay.

Experience has shown that a crop of turnips or swedes sown without a fallow would yield approximate- 
ly 10 tons per acre; after a fallow 20 to 25 tons; after pasture for, say, six years 45 tons per acre. This will improve as the fertility rises; 80 tons per acre would be about top yield in Southland, while Inch Clutha, which is in world class, will yield up to 100 tons per acre.

In the third year the land is disced and cultivated without ploughing. It is then dressed with one ton of lime per acre and sown with turnip or kale. As dry rot and club root will show up in second crops, it is necessary to sow disease resistant types which have been found to be satisfactory. It has not been possible to sow down rape with grass on account of club root which follows two crops of roots.

Rape is recognised as the best fattening feed for lambs. The recent introduction of a club root resistant variety will be of the greatest value where the practice is to sow rape when sowing down.

Up to this stage the land has had a fallow, followed by two crops of turnips or swedes and two tons of lime. It is then sown down to grass with one ton of lime, following working down without using the plough. Occasionally the grass is sown under a cover crop of oats, a feature of this procedure being excellent clover establishment.

Three hundred acres are under the plough ; 150 acres are to be fallowed for one year, that is, until next summer, when it will be worked, limed, and sown in a root crop at the end of November, 1951. Seventy-five acres of last year's fallow will be in a first crop of roots ; 50 acres which were in turnips last year will be sown in a second crop of turnips and kale. This year $26^{\circ}$ acres are available for sowing down, the break in the rotation being due to a certain amount of cultivation being done on the home farm. Although this is a slow method of development, once a rotation is established it has the merit that the land is well worked and levelled out and is in good order for sowing down in grass. It will be realised that from the financial side development is a doublebarrelled proposition. This is because as more work is done the greater are the requirements for stock, sowing down, fencing, liming, and topdressing. This type of development is very attractive compared with that of bush or swamp land where the expenditure may be $£ 10$ per acre or more before a start is made to cultivate or plough.

Crops of turnip, Certified ryegrass, dogstail, and 
white clover have been grown for seed. This has been a considerable assistance when it has been necessary to sow down large areas of pasture.

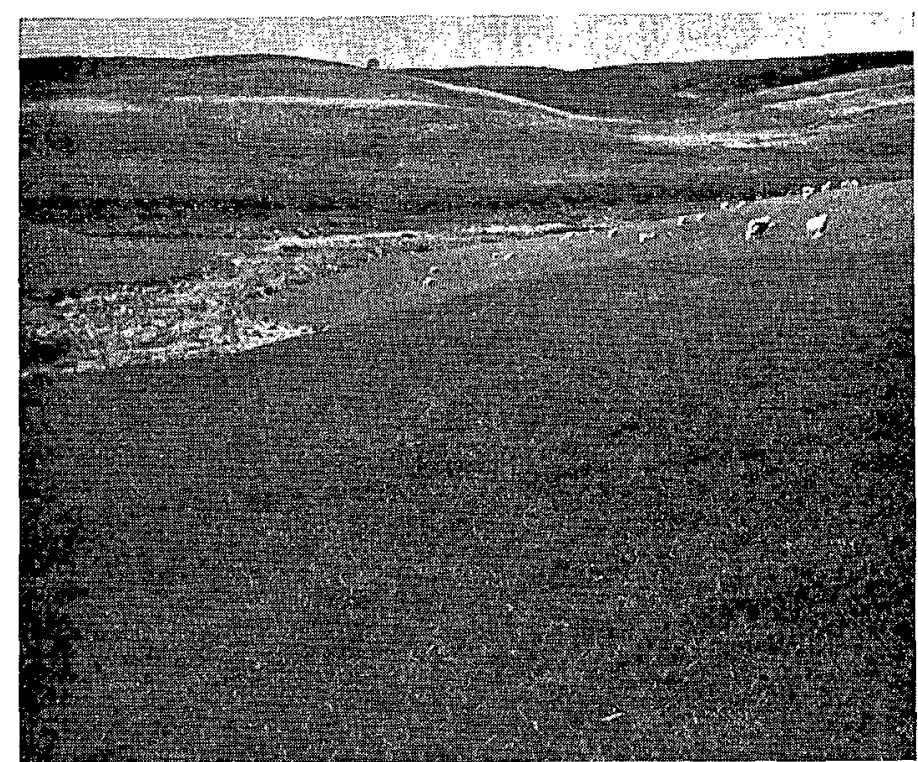

Fig. -2.-First class pastures are established and maintained with the use of Certified seed, lime and fertilisers.

Having had three years of cultivation and three tons of lime per acre, the land has mellowed and is in excellent order for sowing down' to grass. Grass establishment has always been good and the first pasture which was sown in 1939 is satisfactory, although grass grub and rabbits have weakened it in parts. Wet and difficult seasons for haymaking have altered the pasture composition in some cases. However, overall, pastures are reasonably good. The grass seed mixture used consists of the following:-

Certified perennial ryegrass. . 24th per acre Short rotation or Italian ryegrass . 8th per acre Timothy . . . . . 3 3h per acre Cocksfoot . . . 6 to $8 \mathrm{tb}$ per acre White clover . . . . $4 \mathrm{lb}$ per acre

In the earlier stages we carried 4 ewes to each acre sown in grass. This figure has since been reduced to $3 \frac{1}{2}$. However, the 450 acres in grass are now carrying 1,400 Romney ewes and 600 ewe hoggets. 
The percentage of lambs fattened off the mothers has not been high, namely, about 30 per cent. The remaining Romney wether lambs are fattened on supplementary feed or on grass at the home property. Owing to inadequate fencing, cattle are not being used extensively in the meantime.

Generally, we are able to control pasture growth by making hay. However, we do run into difficulties in a damp, growthy season.

Liming is the first essential in development in Southland and with better financial conditions the present capacity of the lime works is taxed to the full. Interesting developments are taking place in the bulk handling of lime, both by the contractor and by individual farmers. Large quantities can be handled quickly and with the minimum effort. About 400,000 tons of lime are being used in Southland each year. Dr. Dixon's recent survey of results of heavy liming in Southland is of particular interest.

The topdressing programme aimed at is $2 \mathrm{cwt}$. of superphosphate per acre plus 5 to $10 \mathrm{cwt}$. of lime annually, but owing to supply difficulties it has not always been possible to apply these quantities.

With varying conditions and values, costs quoted mean very little. In the earlier stages wire cost $£ 29$ per ton, posts $£ 6$, and fencing $6 \mathrm{~s}$. or $7 \mathrm{~s}$. a chain.

The late Sir William Hunt and the Southland Frozen Meat Co. were the pioneers in development on this area. In contrast to my gradual method of development, both of these properties were broken in as a straightout marginal proposition and have been very successful. On Southdown, the Southland Frozen Meat Company property of 5,500 acres, 300 acres per year were broken in mostly by contract costing 20s. to 25s. per acre for ploughing and $6 \mathrm{~s}$. per acre for discing; 900 acres were under cultivation each year. The whole area was finished in 13 years and is now settled by eleven soldier settlers.

On Waitoru Downs, the late Sir William Hunt's property, the land was ploughed about 10in. deep and two tons of lime to the acre were sown following a fallow of about 18 months before sowing turnips. In one paddock the area was sown to pasture following the period of fallowing and liming with excellent results.

The Te Tipua land when developed has a production and stock-carrying capacity equal to much of the heavier land when in many cases draining and tiles would cost $£ 8$ per acre in pre-war days. 